University of Chicago Law School

Chicago Unbound

Journal Articles

Faculty Scholarship

1964

\title{
The New York Times Case: A Note on "The Central Meaning of the First Amendment"
}

Harry Kalven Jr.

Follow this and additional works at: https://chicagounbound.uchicago.edu/journal_articles

Part of the Law Commons

\section{Recommended Citation}

Harry Kalven, Jr., "The New York Times Case: A Note on "The Central Meaning of the First Amendment"," 1964 Supreme Court Review 191 (1964).

This Article is brought to you for free and open access by the Faculty Scholarship at Chicago Unbound. It has been accepted for inclusion in Journal Articles by an authorized administrator of Chicago Unbound. For more information, please contact unbound@law.uchicago.edu. 
HARRY KALVEN, JR.

\section{THE NEW YORK TIMES CASE: A}

\section{NOTE ON"THE CENTRAL MEANING}

\section{OF THE FIRST AMENDMENT"}

\section{Theme}

On occasion the Supreme Court hands down a decision in which past doctrine intersects present events in so complex a way as to be the despair of the commentator, not only because its portent is almost beyond prediction, but also because it opens so many avenues for inquiry. Just such a decision was New York Times Co. v. Sullivan ${ }^{1}$ in which the Court unanimously ${ }^{2}$ held that a libel judgment rendered under Alabama law was violative of First Amendment principles and, therefore, of the Fourteenth Amendment.

Since the case involved a rare instance of measuring the common law of defamation by constitutional standards, ${ }^{3}$ it clamors for a

Harry Kalven is Professor of Law, The University of Chicago.

1376 U.S. 254 (1964).

2 There were, however, three opinions. Mr. Justice Brennan wrote the opinion for the Court. Justices Black and Goldberg each wrote a concurring opinion in which Mr. Justice Douglas joined.

3 The question has arisen before primarily in connection with the absolute privilege of high-ranking government executives. See Barr v. Matteo, 360 U.S. 564 (1959); Spaulding v. Vilas, 161 U.S. 483 (1896); see also Schenectady Union Pub. Co. v. Sweeney, 316 U.S. 642 (1942), where the Court was evenly divided on a question of hibel to a public official. Cf. Beauharnais v. Illinois, 343 U.S. 250 (1952) 
careful determination of how much of that traditional body of tort law is affected by it. And for the torts teacher, it has the dizzying consequence of transmuting a part of his domain-one that he traditionally does not reach until the last day of the semester-into constitutional law, ${ }^{4}$ the Valhalla of the law school curriculum. Moreover, even a cursory examination of the case reveals that the decision was responsive to the pressures of the day created by the Negro protest movement and thus raises the question so frequently mooted whether the Supreme Court has adhered to neutral principles in reaching its conclusion. ${ }^{5}$ And, in this instance, the issue is made particularly attractive by the fact that Herbert Wechsler was counsel to the Times, and brilliantly persuasive counsel at that. ${ }^{\circ}$ It is tempting to ask whether Wechsler the advocate secured a result that Wechsler the critic would condone. ${ }^{7}$ Again, the case is a major instance of the important consequences of the civil rights issue and the apparatus of protest that accompanies it. The Negro movement is making significant constitutional law not only in the area of the Fourteenth Amendment's Equal Protection Clause but in unexpected sectors of First Amendment theory. ${ }^{8}$ Whatever

(group libel and criminal sanctions); Near v. Minnesota, 283 U.S. 697 (1931) (defamation of public officials and injunctive remedy).

4 The question of the constitutionality of the law of defamation has occasioned comparatively little commentary. See Kalven, The Law of Defamation and the First Amendment, in The University of Chicago Law School, Conference on the Arts, Publishing, and the Law 3 (1952); Cahn, Justice Black and First Amendment "Absolutes": A Public Interview, 37 N.Y.U. L. REv. 549 (1962).

5 The basic article is Wechsler, Toward Neutral Principles of Constitutional Law, 73 Harv. L. Rev. 1 (1959).

B Professor Wechsler was not alone on the brief. Herbert Brownell, Thomas F. Daly, and seven other distinguished lawyers and law firms were also of counsel.

A careful comparison of the brief and the opinion of the Court would itself be a profitable enterprise. At various critical points, the opinion echoes the carefully precise language of the brief and the structure of the Court's argument refiects the structure of argument in the brief.

7 However tempting it would be to approach the case in this manner, I think it clear that the opinion satisfies the demand for "neutral principles."

8 I attempted to develop this theme in a series of lectures at the Ohio State Law School in February 1964. These lectures are scheduled to appear early in 1965 as a book entitled The Negro and the First Amendment.

It is worth noting that Mr. Justice Douglas, in a prescient dissent in Beaubarnais, note 3 supra, observed: "Today a white man stands convicted for protesting in 
the irritations and crises of "the long hot summer," the protest has maintained the dignity of political action, of an elaborate petition for redress of grievances. And no one has been more sensitive to this sociological reality than the Supreme Court itself.

Beyond these points, the case raises sharply the question of the relevance of history for constitutional interpretation. In the course of the opinions, the Justices directly confronted the question of the constitutional status of the Sedition Act of 1798. The opinions bypassed what historians like W. W. Crosskey and Leonard Levy have said on the subject ${ }^{9}$ in order to reach the conclusion that, whatever history might suggest, the Sedition Act is now unconstitutional. It is unconstitutional because the reaction after the passage of the Sedition Act precipitated a national consensus to that effect. "[T]he attack upon its validity has," Mr. Justice Brennan stated, "carried the day in the court of history."10 This is heady doctrine. The Court las never before been quite so candid about its use of history. A major issue in constitutional doctrine thus beckons.

This article will not, however, be concerned with the attractions of these four siren songs. Instead it will pursue the significance of the case in yet another dimension, that of First Amendment theory and doctrine. In brief compass, my thesis is that the Court, compelled by the political realities of the case to decide it in favor of the Times, yet equally compelled to seek high ground in justifying

unseemly language against our decisions invalidating restrictive covenants. Tomorrow a Negro will be haled before a court for denouncing lynch law in heated terms." 343 U.S. at 286.

o See Crosskey, Politics and the Constitution 767 (1953); Levy, The Legacy of SuPpression (1960). The very purpose of Dean Levy's book was to ascertain whether the First Amendment was aimed at the abohtion of seditious libel. He concluded: "If, however, a choice must be made between two propositions, first, that the clause substantially embodied the Blackstonian definition and left the law of seditious libel in force, or second, that it repudiated Blackstone and superseded the common law, the known evidence points strongly in favor of the former proposition. Contrary to Justice Holmes, history favors the notion." Op. cit. supra, at 247-48.

The Court did not iguore the Levy book but cited it, correctly, for the view that the meaning of the First Amendment emerged only after the uproar created by the passage of the Sedition Act. Id. at ch. 6. Dean Levy himself did not find the history of the Amendment binding, because the Constitution, at least in the area of civil liberties, "need not be anchored in the past." Id. at 4. For a critical review of the Levy thesis, see Anastplo, Book Reviews, 39 N.Y.U.L. REv. 735 (1964).

10376 U.S. at 276. 
its result, wrote an opinion that may prove to be the best and most important it has ever produced in the realm of freedom of speech. I would make it clear, however, that I am not so much predicting what the Court will do with the case as a precedent as I am suggesting that the opinion makes a notable shift in constitutional idiom and could provide a new start for consideration of free-speech problems. Implicit in this approach is a distinction between the history of legal ideas and precedent, at least at the constitutional level. Certainly the Court's ideas about freedom of speech have commanded as much attention and interest as its rulings.

\section{The FActs: A FiRst VIEW}

I propose to view the facts first in brief compass and then elaborate on them in light of the political demands. The libel action was brought by Sullivan, the police commissioner of Montgomery, Alabama, against four Alabama clergymen, including Reverend Fred L. Shuttlesworth, and the New York Times. The allegedly defamatory publication was a full-page advertisement soliciting contributions for "The Committee To Defend Martin Luther King and the Struggle for Freedom in the South." It consisted largely of editorial comment about the mistreatment by the police and the community of Dr. King and Negro students active in protesting the deprivation of civil rights. ${ }^{11}$ It spoke eloquently of the growing momentum of the protest movement. Its title: "Heed Their Rising Voices," was taken from a New York Times editorial.

The Times was sued as the publisher of the advertisement ${ }^{12}$ and the four clergymen were sued as sponsors and publishers ${ }^{13}$ whose names had appeared prominently in the advertisement along with

11 The third and sixth paragraphs of the advertisement that form the basis for the suit are set out in the text at note 30 , infra.

12 The Court found no significance in the fact that the alleged defamation was contained in a paid advertisement. It sharply distinguished Valentine v. Chrestensen, 316 U.S. 52 (1942), where a commercial advertisement was found unprotected by the First Amendment. "The publication here was not a 'commercial' advertisement in the sense in which the word was used in Chrestensen." 376 U.S. at 266.

13 The Court never reached the question whether these defendants were sufficiently connected with the publication to be treated as publishers. Each of the individual defendants claimed that he had not authorized the advertisement and, in fact, had not seen it prior to the request for a retraction. 
those of some eighty others, none of whom seem to have been amenable to suit in Alabama. The case was tried to a jury which brought in a verdict for $\$ 500,000$ in favor of the plaintiff. A judgment on the verdict was affirmed by the Supreme Court of Alabama. ${ }^{14}$

The Alabama law of defamation appears to have been the same as that of the vast majority of American jurisdictions. It left to the jury the question whether the text of the ad, which did not identify the plaintiff by name or office, referred to the plaintiff..$^{15}$ No specific damages were shown by the plaintiff, but, as is customary under Anglo-American libel law, he was held entitled to a presumption of general damages ${ }^{16}$ and the Alabama Supreme Court declined to find the damages excessive. ${ }^{17}$ The rule of fair comment in Alabama, like that in the majority of jurisdictions in this country, limits the privilege to the expression of defamatory opinions based on facts that are established as true. ${ }^{18}$ In the instant case, the defendants were unable to establish the truth of several of the particulars alleged. The trial court, therefore, withdrew from the jury the question whether the text was defamatory; it held it libelous as a matter of law. ${ }^{10}$ Since the text charged brutality and harassment in the

14273 Ala. 656 (1963). The Alabama court disposed of the constitutional issues in a single paragraph of a lengthy opinion.

15 See, e.g., Gregory \& Kalven, Cases and Materials in Toris 968-73 (1959) (hereafter Gregory \& KALVEN).

16 Id. at 910-26, 930-38.

17 Id. at 926 et seq.; Note, 35 A.L.R. 2d 218-63 (1954).

18 Gregory \& Kalven 1042-58. The basic article on the subject is Noel, Defamation of Public Officers and Candidates, 49 CoLum. L. Rev. 875 (1949); see also Riesman, Demoeracy and Defamation: Fair Game and Fair Comment, 42 Colum. L. Rev. 1085, 1282 (1942); Veeder, Freedom of Public Discussion, 23 HaRv. L. Rev. 413 (1910).

It is arguable that the fair-comment concept has been awkwardly put in the common-law decisions and that what is really involved is the degree to which the underlying facts are disclosed when the opinion is expressed and the inference drawn. Cf., e.g., Eickhoff v. Gilbert, 124 Mich. 353 (1900); Kellems v. California C.I.O., 68 F. Supp 277 (N.D. Calif. 1946); Veeder, supra, at 419-20.

10 The Alabama court spoke of "libel per se" in this connection, apparently meaning no more than the matter was libelous as a matter of law. The phrase has otherwise had a complex and checkered history. See GrEgory \& KalveN 974-81.

In view of the political importance of the Times case, there is historical irony in the fact that the court took the question of defamation away from the jury. The 
execution of police duties, this step also seems unexceptionable under general tort law. Again, the trial court followed the general rule that there is strict liability in defamation and that no actual malice need be proved. ${ }^{20}$ It followed that the misstatement of facts could not be defended on the ground that they were not known to the defendants to be untrue.

The jury was also instructed that it could find punitive damages; that pumitive damages need not have any relation to compensatory damages; but that punitive damages required a showing of actual malice. These are all familiar points of the law of defamation. ${ }^{21}$ The $\$ 500,000$ verdict was not separated by the jury into compensatory and punitive portions. Under Alabama law, punitive damages could not be claimed unless a retraction had been requested and refused. ${ }^{22}$ The plaintiff did request a retraction and the Times did refuse to tender it. In the facts showing the failure to offer a retraction, the Court saw a basis for a finding of malice. Finally, the Alabama court found that the Times was sufficiently engaged in business within the state to subject it to personal jurisdiction and that, in any event, it had, by a general appearance, waived any objection to jurisdiction over its person.

The first point established by the facts is that Alabama did not create any special rules of law for these defendants. It simply applied the existing principles of the law of libel. On the surface, the case does not seem essentially different from such standard precedents as Youssoupof $v$. Metro-Goldwyn-Mayer Pictures, Ltd. ${ }^{23}$ Jones v. E. Hulton \& Co. ${ }^{24}$ Peck v. Tribune Co., ${ }^{25}$ or Marr v. Putnam ${ }^{26}$ It has long been noted that the law of defamation, with its three "galloping presumptions" of damage, falsity, and malice,

great fight over seditious libel in England which culminated in 1792 in the passage of Fox's Libel Act was concerned with right of the jury to define the standard of libel.

20 Gregory \& KaLVEN 982-96.

21 Id. at $926-30$.

22 See Morris, Inadvertent Nerwspaper Libel and Retraction, 32 Ir.. L. REv. 36 (1934).

2350 T.L.R. 581 (C.A. 1934).

24 [1909] 2 K.B. 444 , aff'd, [1910] A.C. 20.

25214 U.S. 185 (1909).

26196 Ore. 1 (1952). 
can produce strangely artificial results. ${ }^{27}$ It is important to stress that the Alabama decision was not simply a sham.

\section{The Facts: A Second View}

The case cannot, of course, be cut off so completely from the turbulent reality that produced it as the statement of facts set out above would do. Certain additional facts must be deemed relevant to the disposition of the issues.

First, the connection of the Times with Alabama could scarcely be more marginal: of the 650,000 published copies of the issues containing the advertisement, ouly 394 were distributed in Alabama, of which 35 were circulated in Montgomery County. ${ }^{28}$ The publication, addressed primarily to a national audience, was all but invisible in the community in which plaintiff was claiming harm to his reputation.

The defamatory import presented an inverse instance of what has become known in the law of defamation as the "wrong-thinking minority problem." 29 The problem usually arises when an assertion about the plaintiff would not be considered defamatory by rightthinking people, e.g., that the plaintiff has Jewish or Negro blood. The rule has been that the court will run the risk of ratifying the prejudice rather than pass on the issue whether the statement ought to have damaged the plaintiff. The plaintiff is entitled to have his reputation protected even among people who do not have "proper" values. The irony in the Times case is that the statements of police brutality and harassment would offend those with the "right" values. What is doubtful is that such allegations did, in fact, offend an Alabama audience, in light of the current exacerbations of the civil rights controversy.

This quirk to one side, there was the difficulty of connecting the statements made by the defendant with the plaintiff, an issue that loomed large in the Supreme Court's handling of the case. Quota-

27 Courtney, Absurdities of the Law of Libel and Slander, 36 AM. L. REv. 552 (1902); Dean, Hatred, Ridicule or ContentPt (1954).

28376 U.S. at 260 n.3.

20 The leading case is Peck v. Tribune Co., 214 U.S. 185 (1909). See also Riesman, supra note 18, at 1300 et seq.; Note, Developments in the Law: Defamation, 69 Harv. L. Rev. 875, 886-87 (1956); Gregory \& KaLven 961-64. 
tion of the two offending paragraphs in the advertisement can spotlight this difficulty: ${ }^{30}$

In Montgomery, Alabama, after students sang "My Country, 'Tis of Thee" on the State Capitol steps, their leaders were expelled from the school, and truckloads of police armed with shotguns and tear-gas ringed the Alabama State College Campus. When the entire student body protested to state authorities by refusing to re-register, their dining liall was padlocked im an attempt to starve them into submission.

Again and again the Southern violators have answered Dr. King's peaceful protests with intimidation and violence. They have bombed his lome almost killing his wife and child. They liave assaulted his person. They have arrested him seven timesfor "speeding," "loitering" and similar "offenses." And now they have charged him with "perjury"-a felony under which they could imprison him for ten years....

The plaintiff argued that as head of the police and responsible for their activities, he was, by inference, charged with: (1) ringing the campus with armed police; (2) arresting Dr. King for spurious offenses. This step, if not compelling, is at least not utterly artificial. Plaintiff claimed further, however, that because these two items referred to him, he would also be understood as one of the persons responsible for: (3) padlocking the dining room and starving the students; (4) bombing the King home; (5) assaulting King; and (6) charging him with perjury. It would seem more reasonable to assume that the "they" referred to in the second quoted paragraph was intended to suggest no specific persons but rather the "Establishment" in which the plaintiff's role would be only incidental. Indeed, both paragraphs would seem to be concerned with such an amorphous group rather than individuals such as the plaintiff.

On a second reading then, there are statements invisibly published in plaintiff's community, which refer to him ouly by a strained construction of their language, and which, given the mood of the day, would not likely be considered defamatory by a southern audience. It is this marginal harm that the jury added up to $\$ 500,000$ damages. One further elenent needs to be added to give the whole picture.

30376 U.S. at 257-58. (Emphasis in original.) 
The gossamer thread on which defendant's liability depended was made thinner by the fact that in order to show that the statements of fact were untrue, plaintiff had to reverse the logic by which he showed that the statements referred to him. On this aspect of the case, he argued that the arrests of Dr. King, for example, occurred before his tenure as commissioner and that as commissioner he had nothing to do with the perjury indictment. Therefore, he asserted, the statements were false as to him. There is revealed here a new technique by which defanuation might be endlessly manufactured. First, it is argued that, contrary to all appearances, a statement referred to the plaintiff; then, that it falsely ascribed to the plaintiff something that he did not do, which should be rather easy to prove about a statement that did not refer to plaintiff in the first place. As it turned out, the Court did not have to confront this logic, which remains tenporarily buried for resurrection at some later time.

The plaintiff did, however, have more traditional allegations of falsity of the statements. And here their relevance to the opinion is of significance. In several nagging particulars, the statements are not absolutely accurate; they reveal an inaccuracy characteristic of hastily drawn newspaper advertisements of this nature. The roster of inaccuracies is something like this: (1) The dining hall was never padlocked. (2) The students did not refuse to reregister. (3) Less than the entire student body protested. (4) The student leaders were not expelled for the protest on the capitol steps. (5) The police at no time literally ringed the campus. (6) Although the police did appear near the campus on three occasions, it was never in connection with the protest at the capitol. (7) Dr. King had not been arrested seven times. (8) The charge that Dr. King was assaulted was flimsy and was based on a single controverted instance of some years before. Nonetheless, almost every allegation had a core of truth. Dr. King had been arrested four times. Police had been deployed near the campus in large numbers. Student leaders had been expelled for taking part in sit-in demonstrations. Most of the student body had protested. The protest had taken the form of boycotting classes.

It is tempting to say that the falsity reduces itself to a charge that Dr. King was arrested seven times rather than four. And that the students sang "My Country 'Tis of Thee," when in fact they sang 
the national anthem. But the other points are not so trivial. And it would prove a disturbing exercise to see what would be left of the first quoted paragraph if all the facts were stated with absolute precision. Since it is characteristic of the common law of defamation to measure the defense of truth against very stringent standards, the conclusion that the falsity of the statements was harmless would not comport with established legal tests. ${ }^{31}$

Perhaps an additional fact has to be taken into consideration. That is that other Montgomery County officials and the Governor of Alabama had also decided that the advertisement defamed them and four additional libel suits were pending seeling judgments against the Times for an additional 2.5 million dollars.

On the second reading of the facts, the inescapable impression is that, although the Alabama law had not been distorted to achieve the result, Alabama somehow pounced on this opportumity to punish the Times for its role in supporting the civil rights movement in the South. The judgment, along with the others that were bound to follow, represented a powerful blow in the South's counterattack. In the civil war that is being waged in the courts as well as elsewhere, the political importance of the case could not be ignored.

One problem among the many that the Court faces in cases of this kind is attributable to the fact that it cannot, like the man in the street, simply state the result that it likes. There may be compelling reasons for decision that it cannot offer publicly without jeopardizing its role and image as a court. The "hard" cases of constitutional law demand high judicial statesmanship. In the Times case, the Court was prepared to pay the high price of destroying a considerable part of the common law of defamation. Whether the price was too high must be determined by the adequacy of the contribution it has made to First Amendment doctrine.

31 See, e.g., Kilian v. Doubleday \& Co., 367 Pa. 117 (1951); Sharpe v. Stevenson, 34 N.C. 239 (1851). The headnote in the Sharpe case reads: "In an action of slander (under our statute) for charging that the plaintiff had criminal intercourse with one $\mathrm{A}$, at a particnlar time and place, the defendant cannot justify by showing that she had such intercourse with $\mathrm{A}$, at another time and place." The common law would seem to have been changed in England by the Defamation Act of $1952, \$ 5$. 15 \& 16 Geo. VI \& 1 Eliz. II, c. 66. 


\section{The Opinion: A First Reading}

There are two readings that may be given the Court's opinion by $\mathrm{Mr}$. Justice Brennan which are, perhaps, only subtly different. But in that small margin of difference is to be found the possibility of a major shift in First Amendment theory.

I start with the narrower reading. The Court began by rejecting the view of the Alabama Supreme Court that libel is beneath constitutional protection. This position was lent credence by dicta in cases like Chaplinsky, ${ }^{32}$ Near, ${ }^{33}$ Pennekamp, ${ }^{34}$ and, especially, Beaubarnais $^{35}$ and $R o t h,^{36}$ none of which was directly concerned with libel. The theme was that the mere labels of state law could not effectively foreclose constitutional scrutiny by the Supreme Court. A year or two ago, the Court had used this thesis brilliantly in penetrating the attempt by the State of Virginia to impose sanctions on the NAACP because it improperly engaged in solicitation of legal business. ${ }^{37}$ Following this line, the Court at the outset refused to permit the door to be slammed against its scrutiny of the judgment on the simple ground that Alabama had called this libel. This sector of the Court's argument concluded with a sentence that echoes the high literacy of the Wechsler brief: ${ }^{38}$ ". . . libel can claim no talismanic immunity from constitutional limitations. It must be measured by standards that satisfy the First Amendment."

Several issues are intertwined here. At the simplest level, it is, of course, correct that the Court cannot permit the concepts of state law to control constitutional scrutiny. If the constitutional principle, for example, is that the state may regulate $X$, the principle can become illusory if the state is left free to define $X$ as it will. What is muted in the opinion are two propositions of a less general and less abstract nature. First there is the fact that Alabama was not creating doctrine for this case in order to call it libel. Second is the existence

32 Chaplinsky v. New Hampshire, 315 U.S. 568 (1942).

33 Near v. Minnesota, 283 U.S. 697 (1931).

34 Pennekamp v. Florida, 328 U.S. 331 (1946).

35 Beauharnais v. Illinois, 343 U.S. 250 (1952).

36 Roth v. United States, 354 U.S. 476 (1957).

37 N.A.A.C.P. v. Button, 371 U.S. 415 (1963). 38376 U.S. at 269. 
of the two-level theory of the First Amendment used by the Court in Beaubarnais to justify regulation of group libel and in Rotb to justify regulation of obscenity. ${ }^{39}$

This screen pushed aside, the Court proceeded to its nuain argument. "The general proposition [is] that freedom of expression upon public questions is secured by the First Amendment." 40 There followed a brief exposition of the "general proposition" supported, among other authorities, by the Brandeis opinion in Whitney. ${ }^{41} \mathrm{It}$ was felicitously summed up in these words: ${ }^{42}$ "Thus we consider this case against the background of a profound national conmitnent to the principle that debate on public issues should be uninhibited, robust, and wide open." The Court thus appeared to command a strong major premise about freedom of discussion of public issues. In a quick stroke, the Court then asserted that the advertisement in the case was "an expression of grievance and protest on one of the major public issues of our time." ${ }^{\text {43 }}$ It would seem, therefore "clearly to qualify for the constitutional protection." "44

The Court then turned to the major task of its lengthy opinion, an exploration of the bases for impeaching the prima facie case made in defense of the advertisement. "The question," said Mr. Justice Brennan of the advertisement, "is whether it forfeits that protection by the falsity of some of its factual statements and by its alleged defamation of respondent." ${ }^{55}$ The answer to this pivotal question is presented in three instalments. First, the Court rejected "any test of truth" as a First Amendment requirement; "factual error affords no warrant for repressing speech that would otherwise be free."46 Second, the Court rejected injury to official reputation as grounds for "repressing speech that would otherwise be free." ${ }^{47}$ And, finally, the Court rejected the conjunction of factual error and injury to official reputation as providing any more adequate basis for overcoming the prima facie case. "This is the lesson to be

39 The effect of the Times case on this line of analysis is considered in the text at notes 111 et seq. infra.

40376 U.S. at 269.

41 Whitney v. California, 274 U.S. 357, 375-76 (1927).

42376 U.S. at 270.

43 Id. at 271 .

44 Ibid.
45 Ibid.

$46 I d$. at 272.

47 Id. at $272-73$. 
drawn from the great controversy over the Sedition Act of 1798. ..." 48

It is at this point that the opinion departed from the impressive clarity and structure with which it had begun. Having disposed of the grounds for impeaching the prima facie case for constitutional protection of the advertisement, the Court could be expected to conclude immediately that the advertisement was entitled to that protection. Instead, however, the opinion moved on to new grounds concerned with the "inhibiting" effect of damage awards. ${ }^{49}$ Apparently it took this position to meet an argument never explicitly made that no restriction on free speech existed in this factual situation because only tort damages and not criminal sanctions are involved. The Court made short shrift of this feeble point: 50 "The judgment awarded in this case-without the need for any proof of actual pecuniary loss-was one thousand times greater than the maximum fine provided by the Alabama criminal statute, and one hundred times greater than that provided by the Sedition Act."

Then the Court returned to an issue that had already been treated: "[T] he state rule of law is not saved by its allowance of the defense of truth." 51 It is difficult to appreciate why that matter had not already been disposed of when the Court so eloquently stated that there is no test of truth in these matters. Originally the point was made that falsity could not be penalized because it was a necessary concomitant of "robust" discussion of public issues. The second time around, the point made was that allowance of truth as a defense could not represent a sufficient policy for protecting freedom of speech because it will impose a kind of "self-censorship" on speakers in the public forum.

In any event, once more the Court had reached the place for ending its opinion. In fact, however, the Court had then just started on its specific grounds for decision. What it required was a rule that would permit good faith error in public discussion. The constitutional rule for fair comment about public officials requires that the plaintiff demonstrate that the falsity was uttered with actual malice. This was, as the Court noted, the minority rule among the American jurisdictions. And its conclusion was buttressed somehow

$481 d$. at 273.

49 1d. at 277.
50 Ibid.

51 Id. at 278. 
by analogy to Barr v. Matteo, ${ }^{52}$ in which the Court had recently stated the government official privilege in the same terms. It would be anomalous, the Court proposed, if the citizen in his official role as critic were to be treated differently from other officials.

The Court then assured that its newly stated rule would not authorize another verdict in the same case on retrial by itself assessing the evidence and determining that it was not adequate to submit the case to the jury. The Court has hitherto rarely displayed such a taste for common sense in deciding a question not directly before it. And then to make assurance doubly sure, it ruled that the evidence was inadequate to connect the plaintiff with the assertions made in the advertisement. This is a powerful point ${ }^{53}$ and causes wonder why the Court did not choose to rest on this issue alone, avoiding the embarrassment of upsetting the rule adopted by a majority of the states on the question of fair comment. Conversely, it is equally puzzling why the Court, having found a fatal defect by reason of the fair comment rule applied, felt compelled to add this second basis for disposition. It is this connndrum that brings me to the second reading of the opinion, the one that contains the seed of important new doctrine.

\section{The Opinion: A Second Reading}

The exciting possibilities in the Court's opinion derive from its emphasis on seditious libel and the Sedition Act of 1798 as the key to the meaning of the First Amendment. My thesis is dependent on four propositions. First, that the importance of the free-speech provision of the Constitution rests on the rejection of seditious libel as an offense. Second, that constitutional history and the traditional analysis had relegated the concept of seditious libel to a curiously unimportant place, although the nagging question of the constitutionality of the Sedition Act of 1798 had never properly been put to rest. Third, that the special virtue of the Times opinion is its restoration of seditious libel to its essential role, thus suddenly and dramatically changing the idiom of free-speech analysis and resolving the question of the constitutionality of the Sedition Act. Finally, that the effect of the Times opinion is necessarily to discard or

52360 U.S. 564 (1959).

53 Cf. Rossman, J., dissenting, in Marr v. Putnam, 196 Ore. 1, 40 (1952). 
diminish in importance the clear-and-present danger test, the balancing formula, the two-level speech theory of Beaubarnais and Roth, and the two-tier theory of different effects of the First Amendment on federal and state action. If I am right, the Times case represents a happy revolution of free-speech doctrine. Or, to put the matter differently, analysis of free-speech issues should hereafter begin with the significant issue of seditious libel and defamation of government by its critics rather than with the sterile example of a man falsely yelling fire in a crowded theater.

My first proposition need not detain us long. The concept of seditious libel strikes at the very heart of democracy. ${ }^{54}$ Political freedom ends when government can use its powers and its courts to silence its critics. My point is not the tepid one that there should be leeway for criticism of the government. It is rather that defamation of the government is an impossible notion for a democracy. In brief, I suggest, that the presence or absence in the law of the concept of seditious libel defines the society. A society may or may not treat obscenity or contempt by publication as legal offenses without altering its basic nature. If, however, it makes seditious libel an offense, it is not a free society no matter what its other characteristics.

My second proposition, the denigration of the importance of seditious libel in establishing First Amendment principles, is more difficult to establish. Perhaps it is only the accident of the sequence in which the speech cases have come to the Court, ${ }^{55}$ combined with the fact that the Court never had the sedition laws before it, that leaves the impression of its disregard of seditious libel and its fascination with the clear-and-present danger formula and balancing. Perhaps it is because we have not used functional categories in working out the theory of free speech. In any event, we do not

54 See generally on the subject of seditious libel, Chafee, Free Speech in the UNITEd States 19 et seq., 497-516 (1948); 2 Stephen, History of the Criminal LAw 299, 353 (1883); Levy, op. cit. supra note 9, at 1-17; Cahn, nore 4 supra; Cahn, Defamation Control v. Press Freedom: A Current Chapter in Israel, 13 J. Pus. LAw 3 (1964).

55 Although Near v. Minnesota, note 33 supra, presented the same problem of seditious libel, the Court, able to dispose of the case on grounds of prior restraint, had no need to confront the more essential issue. 
start with the notion that seditious libel is clearly beyond the power of government and develop our ideas from that proposition. ${ }^{\text {b }}$

Certainly, the logic of the clear-and-present danger test does not foreclose the matter. It leaves the status of seditious libel in doubt. It does not suggest that severe criticism of government policy could never be sufficiently dangerous. Indeed, one might cite Schenck, ${ }^{57}$ Debs, ${ }^{58}$ and $A b r a m 5^{59}$ as three cases in which the Court itself reached the opposite conclusion.

Moreover, until its disposition by the Times case, the status of the Sedition Act of 1798 remained an open question. It has been a term of infamy in American usage, but sober judgments about its constitutionality have been few indeed. Many distinguished commentators-Corwin, ${ }^{60} \mathrm{Hall},{ }^{61}$ and Carroll, ${ }^{62}$ for example-regarded the Sedition Act as constitutional, and Story might also be numbered among them. ${ }^{63}$ Even Chafee, who makes a strong case for the unconstitutionality of the Act in the opening chapter of his classic, seems willing to leave the question unresolved. ${ }^{64}$ More recent re-

56 For example, Professor Emerson, in his careful and thorough inventory of legal analyses of free speech issues, does not give a prominent part to seditious libel. See Emerson, Toward a General Theory of the First Amendment, 72 YALE L. J. 877 (1963).

57 Schenck v. United States, 249 U.S. 47 (1919).

58 Debs v. United States, 249 U.S. 211 (1919).

59 Abrams v. United States, 250 U.S. 616 (1919).

60 Corwin, Freedom of Speech and Press under the First Amendment: A Resumé, 30 YaLE L. J. 48 (1920).

61 Hall, Free Speech in War Time, 21 Colum. L. Rev. 526 (1921).

62 Carroll, Freedom of Speech and of the Press in the Federalist Period: The Sedition Act, 18 Mrch. L. Rev. 615 (1920).

63 Story, 3 Commentaries on the Constitution of the Untred States 743-44 (1833).

64 ChafeE, op. cit. supra note 54, at 28. It is difficult to assess Chafee's position on this point properly. He has deservedly been considered the most influential American writer on free-speech issues and is an important contributor to "the broad consensus" the Court relies on to find that the Sedition Act is unconstitutional. 376 U.S. at 276. And it would seem that Dean Levy regards Chafee as the principal opponent of his thesis that the Framers of the Constitution probably intended to leave the Enghish law of seditious libel unaffected. See Levx, op. cit. supra note 9, at 2 et seq. My point is not that Chafee was insensitive to the tension between seditious libel and democracy, but rather that in his desire to make Holmes the chief 
searches by Crosskey and Levy ${ }^{65}$ have demonstrated how awkward a problem the Sedition Act presents. My point, for the moment, is not to choose the better view of the history of the First Amendment and the Sedition Act, but rather to call attention to the fact that for over 150 years it was not thought necessary to establish the status of the Act as a first step in getting to the meaning of the First Amendment. It was thus possible for the Espionage Act of 1917, as amended in 1918, to contain sections that oddly echoed the idiom of seditious libel: ${ }^{66}$ "language intended to bring the form of government of the United States ... or the Constitution ... or the flag ... or the uniform of the Arniy or Navy into contempt, scorn, contumely, or disrepute." And it was possible for the Government solemnly to urge that the Sedition Act was constitutional in its argument in the Abrams case in $1919 .{ }^{\circ 7}$

Then there was the performance of the Court in 1952 in Beaubarnais $v$. Illinois, ${ }^{68}$ where the majority, in an opinion by $\mathrm{Mr}$. Justice Frankfurter, upheld the constitutionality of a group-libel statute. One might have expected that, in dealing with a question of the application of defamation to comments about a public issue-the alleged activities of Negroes moving into white neighborhoods, the principal task of the Court would be to distinguish group libel from seditious libel. Yet the majority opinion is virtually silent on the point. ${ }^{69}$

I turn, then, to the third proposition concerned with the meaning

architect of American theory he was led to emphasize clear and present danger as the chief analytical tool and to contrast it, not to seditious libel, but to what he called the "bad tendency test."

65 Op. cit. supra note 9.

6640 Stat. 553 (1918); see Chafee, op. cit. supra note 54, at 40-41.

67 It was in response to this argument that Holmes, in dissent, made his prestigious and cavalier dismissal of the Sedition Act: "I wholly disagree with the argument of the Government that the First Amendment left the common law as to seditious libel in force. History seems to me against the notion. I had conceived that the United States through many years has shown its repentance for the Sedition Act of 1798 , by repaying the fines that it imposed." 250 U.S. at 630.

68343 U.S. 250 (1952).

$60 \mathrm{Mr}$. Justice Frankfurter did add a faint cautionary note that libels on political parties would raise "qnite different problems" from those before the Court in Beaubarnais. Id. at 263 n.18. 
of the Court's opinion in the Times case. I suggest that the critical statement in Mr. Justice Brennan's opinion is: ${ }^{70}$ "If neither factual error nor defamatory content suffices to remove the constitutional shield from criticism of official conduct, the combination of the two elements is no less inadequate. This is the lesson to be drawn from the great controversy over the Sedition Act of 1798, 1 Stat. 586 , which first crystallized a national awareness of the central meaning of the First Amendment. See Levy, Legacy of Suppression (1960), at 258 et seq. ..." There follows an extended discussion of the "great controversy," with appropriate quotations from Madison whose views the Court summarizes thus: ${ }^{71}$ "The right of free public discussion of the stewardship of public officials was thus, in Madison's view, a fundamental principle of the American form of government."

The Court then, for the first time in its history and some 166 years after the enactment of the Sedition Act, turned squarely to the issue of its constitutionality. The answer was that "the attack upon its validity has carried the day in the court of history."72 The opinion cited Jefferson, Calhoun, Holmes, Brandeis, Jackson, Douglas, Cooley, and Chafee and concluded: "T3 "These views reflect a broad concensus that the Act, because of the restraint it imposed upon criticism of government and public officials, was inconsistent with the First Amendment."

The Court did not simply, in the face of an awkward history, definitively put to rest the status of the Sedition Act. More important, it found in the controversy over seditious libel the clue to "the central meaning of the First Amendment." The choice of language was unusually apt. The Amendment has a "central meaning"-a core of protection of speech without which democracy cannot function, without which, in Madison's phrase, "the censorial * power" would be in the Government over the people and not "in the people over the Government." This is not the whole meaning of the Amendment. There are other freedoms protected by it. But at the center there is no doubt what speech is being protected and no doubt why it is being protected. The theory of the freedom of speech clause was put right side up for the first time.

70376 U.S. at 273. Cf. Brief for the Petitioner, The New York Times, 45-46.

71376 U.S. at 275.

72 Id. at 276.

73 Ibid. 
Although the total structure of the opinion is not without its difficulties, it seems to me to convey, however imperfectly, the following crucial syllogism: The central meaning of the Amendment is that seditious libel cannot be made the subject of government sanction. The Alabama rule on fair comment is closely akin to making seditious hibel an offense. The Alabama rule therefore violated the central meaning of the Amendment.

If the opinion can be read in this way, what emerges as of large importance is the generous sweep of the major premise and not the application of it to the point of defamation law involved in the Times case. The touchstone of the First Amendment has become the abohition of seditious libel and what that implies about the function of free speech on public issues in American democracy. The drama of the Times case then is that the Court, forced to extricate itself from the political impasse that was presented to it, did so by returning to the essence of the First Amendment to be found in its limitations on seditious libel. It gets to very high ground indeed.

There are two other portions of the opinion, already noted, that confirm the proposition that the Court is carried along by a momentun of insight about the democratic necessities for free speech. There is the analogy to Barr v. Matteo ${ }^{74}$ and the privilege of the high-ranking government executive. The rationale in Barr was that the threat of damage suits would dampen the ardor of the official for the performance of his duties. "Analogous considerations support the privilege for the citizen-critic of government. It is as much his duty to criticize as it is the official's duty to administer."75 It is now not only the citizen's privilege to criticize his government, it is his duty. At this point in its rhetoric and sweep, the opinion almost literally incorporated Alexander Meiklejohn's thesis that in a democracy the citizen as ruler is our most important public official. ${ }^{76}$

Then there is the alternative ground for judgment concerned with the inadequate linking of the plaintiff to the language of the advertisement. If such connection is too easily made, all criticism of government policy, however inipersonal, will carry implicit

74360 U.S. 564 (1959). 75376 U.S. at 282.

76 Meiklejohn, Poltrical Freedom: The Constrtumonal Powers of the People 34-36 (1948). 
defamation of whatever officials were in charge of the policy attacked. Such a rule of construction, said Mr. Justice Brennan, "would sidestep this [constitutional] obstacle by transmuting criticism of government, however impersonal it may seem on its face, into personal criticism, and hence potential libel, of the officials of whom the government is composed. There is no legal alchemy by which a State may thus create the cause of action that would otherwise be denied. . .."77 And then, to underscore the centrality of seditious libel for the First Amendment, Mr. Justice Brennan added: ${ }^{78}$ "Raising as it does the possibility that a good faith critic of government will be penalized for his criticism, the proposition relied on by the Alabama courts strikes at the very center of the constitutionally protected area of free expression."

When these three passages are taken together, it becomes evident that the Court was not simply uttering, as the Court is wont to do, the occasional sentence that reads felicitously even out of context. It was clearly being driven by a concern for the central meaning of the First Amendment.

\section{Truth, Falsity, and Freedom of Speech}

The Court's confrontation of the relevance of truth to a constitutional doctrine of free speech, closely related as it is to the idea of seditious libel, requires further consideration. Here again Mr. Justice Brennan's observations are refreshing because they far transcend in importance the resolution of the specific issue before the Court.

The question may be asked: Does the constitutional protection of freedom of speech simply establish the right to utter the truth? History makes clear that this would be no inconsiderable freedom. ${ }^{70}$ Certainly there are various interesting limitations in contemporary law on the immunity of truth tellers. ${ }^{80}$ The critical question, however, is whether falsity must not also be protected. The classic de-

77376 U.S. at 292.

78 Ibid.

79 It must be acknowledged that a good part of the historic controversy over seditious libel centered on the defense of truth. See note 54 supra.

80 Franklin, A Constitutional Problem in Privacy Protection: Legal Inbibitions on Reporting of Fact, 16 STAN. L. REv. 107 (1963); The Origins and Constitutionality of Limitations on Trutb as a Defense in Tort Law, id. at 789 (1964). 
fenses of freedom of speech have all suggested that the truth should not be used to discriminate between permissible and impermissible speech, at least at the level of ideas. More recently the point has been effectively put by Alexander Meiklejohn: ${ }^{81}$ "The vital point $\ldots$ is that no suggestion of policy shall be denied a hearing because it is on one side of the issue rather than another. . . . These conflicting views may be expressed, must be expressed, not because they are valid, but because they are relevant."

For at least a generation it has been the prevailing notion that at the level of doctrine and ideas the Constitution did not distinguish between the true and the false. ${ }^{82} \mathrm{~A}$ short time ago, the proposition was admirably summed up by Mr. Justice Stewart in the Kingsley Pictures case which was concerned with a state ban on the movie based on Lady Chatterley's Lover: ${ }^{83}$

It is contended that the State's action was justified because the motion picture attractively portrays a relationship which is contrary to the moral standards, the religious precepts, and the legal code of its citizenry. This argument misconceives what it is that the Constitution protects. Its guarantee is not confined to the expression of ideas that are conventional or shared by a majority. It protects advocacy of the opinion that adultery may sometimes be proper, no less than advocacy of socialism or the single tax. And in the realm of ideas it protects expression which is eloquent no less than that which is unconvincing.

What has been less clear was the vulnerability to legal discipline of false statements of fact. And it was to this issue that Mr. Justice Brennan spoke with such force in the opinion in the Times case. False statements of fact, at least on public issues, are apparently to be afforded constitutional protection. Two different rationales were tendered in support of this proposition. There was stress on the likelihood that errors of fact will be made. The Court, thus, approvingly quoted from Cantwell's behavioral dictum: "To persuade

81 Meiklejohn, Polttical Freedom 26-28 (1948).

82 Indeed it was a principal puzzle of the Scopes case, for example, that the situation seemed to require the court to make a choice between truth and falsity. See Kalven, Emerson, Haber, \& Sharp, The Scopes Case: A 1960 Vierw, 27 U. CH. L. Rev. 505 (1960).

83 Kingsley Pictures Corp. v. Regents, 360 U.S. 684, 688-89 (1959).

84 Cantwell v. Connecticut, 310 U.S. 296, 310 (1940), quoted 376 U.S. at 271. 
others of his own point of view, the pleader, as we know, at times resorts to exaggeration, to vilification of men who have been or are prominent in church or state, and even to false statement." The Court went on to state: ${ }^{85}$ ". . . erroneous statement is inevitable in free debate, and ... must be protected if the freedoms of expression are to have the "breathing space' that they 'need . . . to survive." Once again we are reminded that the national commitment is to debate on public issues that is "uninhibited, robust, and wide open."

The Court is also moved, however, by the difficulty of proving truth in these matters, and of putting the speaker to the risk of proof before fallible judges, juries, or administrative officials. In dealing with this proposition, the Court, put together Smith v. California ${ }^{86}$ and Speiser $v$. Randall ${ }^{87}$ to suggest a new category of invalid regulations: laws that tend to inhibit freedom of speech by generating a kind of "self-censorship." Thus, the bookseller in Smith, if left under so loose a requirement of scienter of obscenity, would tend to restrict the books he sells to those he has inspected. The law would then set off a chain reaction of self-censorship "affecting the whole public, hardly less virulent for being privately administered." 88 And the citizen seeking tax exemption in Speiser, confronted with the loyalty test there involved which left the burden of proof on the applicant, would become comparably reticent. "The man who knows that he must bring forth proof and persuade another of the lawfulness of his conduct necessarily must steer far wider of the unlawful zone than if the State must bear these burdens." would be deterred from uttering what was in fact true "because of doubt whether it can be proved in court or fear of the expense of having to do so."90 Thus the special vice of such a law is that it introduces a self-censorship that invades the zone of permissible and

85376 U.S. at $271-72$.

86361 U.S. 147 (1949). See Kalven, Metaphysics of the Law of Obscenity, [1960] SuPREME Court ReVIew 1, 35 et seq.

87357 U.S. 513 (1958). See Kalven \& Steffen, The Bar Admission Cases: An Unfinished Debate between Justice Harlan and Justice Black, 21 LAW IN TRANs. 155, 179 et seq. (1961).

88361 U.S. at $153-54$.

88357 U.S. at 526.

89376 U.S. at 279. 
lawful speech. From these three cases, all written by Mr. Justice Brennan, emerges a fascinating and promising judicial utilization of psychology.

It must be recognized, of course, that a reason implicit in the breadth of the protection afforded speech is due to the judicial recognition of its own incapacity to make nice discriminations. It reflects a strategy that requires that speech be overprotected in order to assure that it is not underprotected. In any event, the Times opinion is as great a contribution to the issue of the relevance of truth to protected speech as it is to the issue of the relevance of the doctrine of seditious libel.

\section{VII. "Where Are They Now?"}

A not unfamiliar bit of Americana is a series of New Yorker articles that ran some years ago under the rubric "Where are they now?" The articles concerned with once familiar personages who seemed to have disappeared from the scene. ${ }^{11}$ In the world of constitutional ideas and formulas, it becomes pertinent, after the Times case, to ask the same question about once familiar legal doctrines totally ignored by the opinion. Where are they now?

\section{A. THE CLEAR-AND-PRESENT DANGER TEST}

It has become a commonplace for commentators on constitutional law to note that the clear-and-present danger test is not flourishing these days. Thus, so careful a student as Professor Thomas I. Emerson recently concluded that the test may have been abandoned by the majority of the Court. ${ }^{22}$ Whether the rewriting of it by Judge Learned Hand in the Dennis case ${ }^{93}$ or the persistent attack on it as a constitutional formula by Mr. Justice Frankfurter ${ }^{94}$ or the perplexities of the newer speech issues or the sheer inadequacy of the formula itself caused its decline may be unclear. But it is clear

91 The leading right-to-privacy case arose out of one of the articles in this series. See Sidis v. F-R Publishing Corp., 113 F.2d 806 (2d Cir. 1940). Nerwsweek now runs a weekly feature under the same title.

92 Emerson, supra note 56, at 912.

93 United States v. Dennis, 183 F.2d 201 (2d Cir. 1950).

94 See, e.g., his concurring opinion in Dennis v. United States, 341 U.S. 494, 517 (1951). 
that, as of the judgment in the Times case, it has disappeared. It did not occur to the Court to test the Alabama law before it in terms of clear and present danger, ${ }^{95}$ although barely a decade before, in Beaubarnais, appeal to that test was the principal argument of the defendant..$^{96}$ (It was one of the astute and successful gambles of the Wechsler brief that it did not argue the case in terms of clear and present danger.) The measure of the conceptual revolution promulgated by the Times case is that the Alabama law is found unconstitutional, not because there is no clear and present danger of a substantive evil in defendants' speech, but because the law looks too much like punishment for seditious libel.

There was one mention of the clear-and-present danger test in the majority opinion. It occurred in a reference to Pennekamp $v$. Florida ${ }^{97}$ when the Court analogized the problem of defamation with that of contempt of court by publication. It would seem that the contempt problem is at least a sibling if not a twin to the one presented in the Times case. The former involves defamation of a specific public official, a judge. It might have been expected, therefore, that the same solution would fit both problems. But the modern Supreme Court decisions on the contempt problemBridges $_{\lambda}^{98} \mathrm{Craig}^{99}$ and Pennekamp-all rely for their disposition on the clear-and-present danger test. And as recently as 1962, in Wood v. Georgia, ${ }^{100}$ the Court adhered to this approach in disposing of a contempt case. The contempt cases make the Court's silence in the Times case on the viability of the clear-and-present danger test all the more deafening.

\section{B. BALANCING}

Immediately prior to the Times decision, the fashionable First Amendment test was what Professor Emerson called "ad hoc bal-

\footnotetext{
95 It is certainly not easy to apply the test to a defamation case. A try at it was made, but with what success? See Kalven, supra note 4, at 12-13.

${ }^{96}$ The expectation that the Court would have to confront the clear-and-present danger test in an obscenity case survived until 1957. See Kalven, nore 86 supra.

97328 U.S. 331 (1946).

98 Bridges v. California, 314 U.S. 252 (1941).

99 Craig v. Harney, 331 U.S. 367 (1947).

100370 U.S. 375 (1962).
} 
ancing." This formula, which he dates from the Douds ${ }^{101}$ case in 1950, has been the subject of several celebrated debates within the Court, especially between Justices Black and Harlan. The controversy has centered on large issues about absolutes and the proper role of judicial review. ${ }^{102}$ Professor Emerson, a critic of the balancing formula, has defined it: ${ }^{103}$ "The formula is that the court must, in each case, balance the individual and social interest in freedom of expression against the social interest sought by the regulation which restricts expression."

It is scarcely a novel suggestion that the law of defamation with its strict liability on the one hand and its complex of offsetting privileges on the other is a prime example of balancing the interest in freedom against the social interest sought by inhibiting communication. ${ }^{104}$ It is this balancing that in fact generates the bullk of the law in this area and the special fascination that it has derives from the precision and detail with which the comnion law has struck the balance in different situations. The issue before the Court in the Times case, therefore, would have been peculiarly meet for the application of the balancing formula. Again the failure to speak to the issue, either in the Court's opimion or Mr. Justice Black's concurrence, suggests the necessity for its re-evaluation.

The point, lowever, is even stronger. In substance, the Court adopted as its constitutional principle the so-called minority view of Coleman v. MacLennan, ${ }^{105}$ an old Kansas case that Mr. Justice Brennan quoted with approval. Coleman contains a stunning, extensive opimion by Justice Burch of the Kausas Supreme Court. The Burch opinion may well be the most elaborate, careful, extended act of balancing in the history of American law. It is one long, able dialogue on the problem. If ever a case was appropriate for the

101 American Communications Association, C.I.O. v. Douds, 339 U.S. 382 (1950). 102 See Black, The Bill of Rights, 35 N.Y.U. L. REv. 865 (1960); Meiklejohn, The First Amendment Is an Absolute, [1961] Supreme Court Review 245; Tbe Balancing of Self-Preservation against Political Freedom, 49 CALIF. L. REv. 4 (1961); Frantz, The First Amendment in the Balance, 71 YALE L. J. 1424 (1962).

103 Emerson, supra note 56, at 912.

104 Any good torts casebook makes this apparent. See, e.g., Gregory \& KaLvex 996-1064.

10578 Kan. 711 (1908). 
application of the balancing test, the Times case was. But, from the Court, only silence.

The silence here, however, does not suggest the same result as the silence accorded the clear-and-present danger test. It means only that the balancing cases have been treated as having too wide an application. The philosophic debate over balancing lias overshot the actual area of controversy. Whatever the Court may have said, it has never used the balancing formula except in a limited type of speech case, ${ }^{108}$ a category in which the Times case did not fall.

A distinction must be drawn between cases in which legal sanctions are imposed for the specific purpose of restricting speech and those in which the control of speech is a by-product of government action that is otherwise permissible. Douds, ${ }^{107}$ Bates, ${ }^{108}$ and Konigsberg, ${ }^{109}$ for example, did not involve the direct application of a sanction intended to deter speech. It is in these cases that the Court has sought to solve the problems before it by some effort to balance the state's acknowledged interest against the resulting interference with speech. It seems to me that in this regard Mr. Justice Harlan has been clearer than Mr. Justice Black as to the precise scope of the issue. Mr. Justice Harlan would not balance in the ordinary case, but only in these curiously oblique speecl cases where he sees no way to avoid it. ${ }^{110} \mathrm{Mr}$. Justice Black, on the other hand, often appears to treat the issue as if it involved a reappraisal of all First Amendment cases. And he insists that if there is any governmentally initiated interference with speech, however unintended and however slight, the action is unconstitutional.

I do not mean liere to pass judgment on which of the Justices has the better of the argument, but only to stress that the speech issue involved in the Times case is different in kind from those in which the Court has utilized its balancing formula. The intended function of the tort law was to discipline certain kinds of speech. The importance of the silence of the Times case on the balancing test is that it cuts it down to its appropriate size.

108 See Kalven \& Steffen, supra note 87.

107 Note 101 supra.

108 Bates v. Little Rock, 361 U.S. 516 (1960).

109 Konigsberg v. State Bar of California, 366 U.S. 36 (1961).

$110 \mathrm{Id}$. at 51. 
There is, of course, a sense in which the Court did indulge in balancing. It did not go the whole way and give an absolute privilege to the "citizen-critic." It left open the possibility of liability where the defendant's actions were the result of actual malice. Like Justice Burch, therefore, it has balanced the two obvious conflicting interests. Nonetheless, the idiom of balancing was eschewed in the Times case not only by the majority but by the concurring opinions as well.

\section{THE TWO-LEVEL THEORY ${ }^{111}$}

Beginning with Chaplinsky, ${ }^{112}$ in 1942, and emerging as the central point of Beaubarnais ${ }^{113}$ in 1952 and Rotb ${ }^{114}$ in 1957, the Court developed a special technique for fitting certain kinds of freespeech problems into the constitutional framework. The technique consisted of dividing speech into two categories: that which is worthy enough to require the apphication of First Amendment protection and that which is beneath First Amendment concerns. The litany of lower-level speecl, so often quoted from Cbaplinsky, runs as follows: 115 "There are certain well-defined and narrowly limited classes of speecl, the prevention and punishment of which has never been thought to raise any Constitutional problem. These include the lewd and obscene, the profane, the libelous, and the insulting or figliting words." This passage had served the Court well in disposing of the problem of group libel in Beaubarnais and of obscenity in Roth. It is not quoted in the Times case.

In this instance, however, the point is not passed over in silence. The plaintiffs had urged as a principal argument in defense of the judgment that libel was not constitutionally protected. The Court confronted the issue directly and disposed of it firmly: ${ }^{110}$ "... 'mere labels' of state law" cannot control constitutional judgment; "libel can claim no talismanic immunity from constitutional limitations. It must be measured by standards that satisfy the First Amendment." No matter how speech is classified, there must still be First Amendment consideration and review. No category of speech is any

111 This awkward phrase is my own. See Kalven, note 86 supra.

112 Note 32 supra.

113 Note 35 supra.

115315 U.S. at 571-72.

114 Note 36 supra. 116367 U.S. at 269. 
longer beneath the protection of the First Amendment. Had the Times case preceded Roth, for example, Rotb could not have been written the way it was, although the decision might have been the same. Obscenity, too, it would seem, "can claim no talismanic immunity from constitutional limitations."

The special logic of Chaplinsky, Beaubarnais, and Rotb may well disappear now that the Times opinion is on the books. The twolevel theory may, in any event, have been the consequence of an attempt to avoid the clear-and-present danger test. Now that that test has been obliterated, there may no longer be a need for the special technique developed to deal with it.

D. THE TWO-TIER THEORY OF THE FIRST AND

FOURTEENTH AMENDMENTS

The final pocket of Supreme Court ideology affected by the Times case is a special view of federalism. The view was expressed primarily by $\mathrm{Mr}$. Justice Jackson in Beaubarnais and by Mr. Justice Harlan in Roth. It has never received the sanction of a majority of the Court. ${ }^{117}$ The point of the argument is that the First Amendment as applied to the federal government has a different and more stringent meaning than the Fourteenth Amendment when it incorporates the standards of the First in application to the states.

In the Times case, the Court upset a common-law rule followed in the great majority of the states. The situation seemed ripe for the utilization of the two-tier suggestion. The states might well have been given some leeway in experimenting with what Coleman $v$. MacLennan ${ }^{118}$ treated as a close policy question. Once again the arresting fact is that Mr. Justice Harlan let his pet theory go by default. Apparently we need a single national policy on the privilege of fair comment. We are, after all, talking about seditious libel and the core of the First Amendment.

In one brief passage, $\mathrm{Mr}$. Justice Brennan spoke directly to the two-tier thesis and rejected it. The plaintiffs liad apparently argued

117 See Kalven, supra note 86, at 2I-23. A thoughtful theoretical argument for federalism in the free speech area has recently been put forward. See Anastaplo, Notes on the First Amendment (unpublished $\mathrm{Ph} . \mathrm{D}$. thesis University of Chicago 1964).

118 Note 105 supra. 
that "the constitutional limitations implicit in the history of the Sedition Act apply only to Congress and not to the States." 119 It did not unnerve the Court that this seemed to have been the view of Thomas Jefferson. ${ }^{120}$ The thesis was that the furor over the Sedition Act was the expression of a view about federalism rather than about freedom of speech. The Court, in a grand but illogical gesture, disposed of the challenge summarily: ${ }^{21}$ ". . . this distinction was eliminated with the adoption of the Fourteenth Amendment and the application to the States of the First Amendment's restrictions." The argument presumably is that limitations on federal power that have their origin in a deference to state power become by the alchemy of the Fourteenth Amendment limitations on state power.

\section{The Concurring Opinrons}

In separate concurring opinions, in each of which Mr. Justice Douglas joined, Justices Black and Goldberg argued essentially the same objection, ${ }^{122}$ that the majority did not go far enough to provide adequate protection to critics of official conduct. The minority would make an absolute privilege where the majority created only a qualified one that was defeasible on proof of actual malice. It is possible to speculate on the reasons why the Court stopped short of absolute privilege. The more important question, however, is whether the failure to go all the way impeached the majority's major premise. Has it spoiled the sweep of its powerfnl new reading of the First Amendment?

Certainly if the "citizen-critic" is now to be viewed as a public official and if strength is to be borrowed from the analogy of the privilege given public officials by Barr v. Matteo, it is difficult to see why the citizen is given a lesser privilege than the official. Perhaps a distinction might be based on the difference in numbers between officials and citizens. Arguably the official is a more vulnerable tar-

119376 U.S. at 276.

120 See Levy, Jefrerson and Civil Liberties: The Darker Side (1963).

121376 U.S. at 277.

${ }_{122}$ The one difference between the opinions would seem to be that Mr. Justice Goldberg would retain an area of private life in which a public official would have the benefits of the ordinary rules of defamation. He is not dismayed by the difficulty of drawing this distinction. 376 U.S. at 302 n.4. 
get for harassment, because there are so few of him and so many of the public. Equally troublesome may be the Court's premise about "self-censorship." If the citizen cannot be put to the hazards of proving truth without deterring him from risking certain useful criticism, is not the same censorship generated by a rule that leaves on him the risk of proof of malice? Here the answer would seem to be that the risks are different because the burden of proving both falsity and malice are now on the plaintiff.

If the majority opinion does seem to have the worst of the debate on these two points, there remain three important countervailing considerations in support of its view. First, the Court's concern has been with the kind of inevitable factual error and exaggeration that are not extraordinary accompaniments of robust criticism. It is willing to forgive this kind of error. Its affirmative pohicy need not extend to deliberate falsehoods. Second, the Court was showing considerable daring in upsetting so long-standing a rule of common law that prevailed in so large a majority of the states. To hold in favor of absolute privilege would upset the common-law rule in all the states. Finally, it should be remembered that the Court was not dealing simply with Negro defamation of southern public officials. It was dealing with a general rule for limitation of criticism of public officials. The Court makes actual mahice a "constitutional fact" that it will review de novo and indeed did review de novo in the case itself. There is thus some protection afforded against a too facile or disingenuous finding of the existence of malice.

I would conclude that the majority opinion survives the concurring opinions in good shape. There can be something demeaning in carping too much about the illiberality of so distinctively liberal an opinion. ${ }^{123}$

\section{Conclusion}

We get a sense of difference between a legal theory of freedom of speecli and a philosophic theory as we trace the career of

$123 \mathrm{Mr}$. Justice Goldberg does try for a neat debater's point about the constitutionality of the Sedition Act under the standard of the Court's opinion. The Sedition Act, too, provided for prosecutions for malicious statements. But the point was long ago disposed of by establishing the difference in meaning between "actual malice" as used in the Court's opinion and constructive malice that would satisfy the Sedition Act. See Bromage v. Prosser, 4 B. \& C. 247 (1825); Smith, Jones v. Hulton: Tbree Conflicting Judicial Vierws as to a Question of Defamation, 60 U. PA. L. REv. 365 (1912). 
seditious libel from seventeenth-century England through Fox's Libel Act through the Sedition Act to the Times case. It is one thing to assert that a vigorous criticism of the government must be permitted. It is another to choose among the cahibrations of freedom that legal institutions and procedures can provide. Initially the great issue about seditious libel was whether judge or jury would have the final say as to what was defamatory of the government. The effect of Fox's Libel Act was simply to shift control from the judges to the juries, from the government and its judges to the people themselves. Then it became important to establish truth as a defense. ${ }^{124}$ And, finally, in the Times case the critical area involves the degree of privilege to be afforded statements that are not true. We are reminded not only of how nuch more complex the legal debate over freedom of speech or over seditious libel can be, but again of the arresting problem how much freedom of speech in a legal system must depend on law's conscious distrust of its own processes to make needed discriminations.

The closing question, of course, is whether the treatment of seditious libel as the key concept for development of appropriate constitutional doctrine will prove germinal. It is not easy to predict what the Court will see in the Times opinion as the years roll by. It may regard the opinion as covering simply one pocket of cases, those dealing with libel of public officials, and not destructive of the earlier notions that are inconsistent only with the larger reading of the Court's action. But the invitation to follow a dialectic progression from public official to government policy to public policy to matters in the public domain, like art, seems to me to be overwhelming. If the Court accepts the invitation, it will slowly work out for itself the theory of free speech that Alexander Meiklejohn has been offering us for some fifteen years now. ${ }^{125}$

124 It is an instructive quirk of history that the Sedition Act of 1798 has come down to us as odious legislation while Fox's Libel Act of 1792 is seen as a milestone on the march to hiberty. Yet the Sedition Act followed Fox's Libel Act in providing jury trial and went further by affording the defendant the defense of truth. The fact that this liberalizing of the law of seditious libel was viewed so dimly in the United States suggests, to my mind, some doubts about the validity of Dean Levy's thesis as to the common understanding prior to the Sedition Act crisis.

${ }^{125}$ It is perhaps a fitting postscript to say that I had occasion this summer to discuss the Times case with Mr. Meiklejohn. Before I had disclosed my own views, I asked him for his judgment of the Times case. "It is," he said, "an occasion for dancing in the streets." As always, I am inchined to think he is right. 
HeinOnline -- 1964 Sup. Ct. Rev. 2221964 